Northern Development, Wasagaming, Manitoba. Unpublished manuscript.

"GODFREY, W. E. 1953. Notes on the birds of the area of intergradation between eastern prairie and forest in Canada. Nat. Mus. of Canada, Bull. 128: $189-240$.

3MACARTHUR, R. H. 1958. Population ecology of some warblers in northeastern coniferous forests. Ecology, 39: 599-619.

${ }^{4}$ MORSE, D. H. 1967. The context of songs in black-throated green and blackburnian warblers. Wilson Bull., 79: 1-128.

\section{CLARKE'S NUTCRACKER}

\section{AT SASKATOON}

\section{by STAN SHADICK*}

On November 18, 1972, Mr. Ben Simpkins who owns a farm at Beaver Creek, 8 miles south of Saskatoon, reported to us that there was a strange bird in his yard. He had looked it up in a birdbook and decided that it must be a Clarke's Nutcracker. Realizing this to be far from its normal range, John Shadick, Ron Bobowski and I went to have a look at it in the afternoon. Upon arrival, we saw the bird in a shelter belt some 10 yards from the farmhouse. The long pointed bill, white patches on otherwise black wings and tail, as well as the jay size enabled us to confirm the identification as a Clarke's Nutcracker, a species which my dad and I have seen several times in the Rockies. The bird was generally darker than that shown in pictures of adult birds, indicating it to be an immature.

While we watched, the bird appeared quite tame and allowed us to approach to within 15 feet. During this time it was feeding on a recently slaughtered pig's head as well as some sausage meat which had been set out for it.

Before leaving I reported the sighting to the local "Rare Bird Alert" and

\footnotetext{
* 810 Main St.
}

Saskatoon, Saskatchewan.
'PETERSON, R. T. 1956. A field guide to th birds. Houghton Mifflin Co., Cambridge. 161

"SOPER, J. D. 1953. The birds of Riding Monutuai National Park, Manitoba, Canada. Can. Wild Serv., Wildl. Mgt. Bull. Series 2, No. 6. 54 p

'TAVERNER, P. A., and R. SUTTON. 194( Preliminary annotated list of birds, Riding Mou, tain Notional Park. Manitoba. Natl. Mus. Car Mimeographed Manuscript.

several observers from Saskatoon wer able to come out and view this rarity Dr. Stuart Houston brought out a tra to band the bird but was unsuccessfu The nutcracker was able to steal the ba without getting caught. Alan Mouli reported that he had no trouble in ar proaching within 8 feet of the bird. Th bird was last seen by the Simpkin famil on November 23.

According to Salt and Wilk, th Clarke's Nutcracker is restricted to th sub-alpine coniferous forests of th mountains in summer, but descends $t$ lower altitudes in late fall and winter On these occasions it has been see frequenting settlements and farmyards.

There have been several records this species at great distances from it breeding range. In Alberta, it has bee seen at Porcupine Hills, Beaver Lodg and Belvedere.' In Saskatchewan, it ha been seen on several occasions in th Cypress Hills region as well as at Moos Jaw on March 24, 1968. ${ }^{24}$ There are i addition at least two records fo Manitoba.' However, this sighting Saskatoon represents a significant rang extension. of this straggler for Saska chewan.

'GODFREY, W. E. 1966. The Birds of Canad' Nat. Mus. of Can. Bull. No. 203, Ottawa.

${ }^{2}$ GREEN, D. S. 1969. Clarke's Nutcracker at Moo Jaw. Blue Jay 27: 36.

'SALT, W. R., and A. L. WILK. 1966. The Birds Alberta. Dept. of Industry and Development, Er monton.

${ }^{4}$ SEALY, S. G. 1971. The occurrences of son western birds in Saskatchewan. Blue Jay 29: 18 196. 